\title{
Salt stress and temperatures on the germination and initial growth of 'jurema-de-embira' (Mimosa ophthalmocentra) seedlings
}

\author{
Narjara W. Nogueira ${ }^{1}$, Salvador B. Torres ${ }^{1}$, Rômulo M. O. de Freitas ${ }^{2}$, \\ Paulo C. da S. Santos ${ }^{1}$, Francisco V. da S. Sáa \& Moadir de S. Leite ${ }^{1}$ \\ ${ }^{1}$ Universidade Federal Rural do Semi-Árido/Centro de Ciências Agrárias/Departamento de Ciências Agronômicas e Florestais. Mossoró, RN. E-mail: \\ narjara.nogueira@ufersa.edu.br (Corresponding author) - ORCID: 0000-0003-0668-3327; sbtorres@ufersa.edu.br - ORCID: 0000-0003-0668-3327; \\ paulocesaref@hotmail.com - ORCID: 0000-0001-7428-4091; moadir@outlook.com - ORCID: 0000-0003-0432-0522 \\ ${ }^{2}$ Instituto Federal de Educação, Ciência e Tecnologia Baiano/Campus Valença. Valença, BA. E-mail: romulomagno_23@hotmail.com - ORCID: 0000- \\ 0002-2422-0118 \\ ${ }^{3}$ Universidade Federal de Campina Grande/Centro de Tecnologia e Recursos Naturais/Unidade Acadêmica de Engenharia Agrícola. Campina Grande, \\ PB. E-mail: vanies_agronomia@hotmail.com - ORCID: 0000-0001-6585-8161
}

\section{Key words:}

Fabaceae

forest species

caatinga

salinity

\begin{abstract}
A B S T R A C T
The objective of this study was to evaluate the effects of salinity on the germination and initial growth of 'jurema-de-embira' (Mimosa ophthalmocentra) seedlings at different temperatures. The experiment was installed in a completely randomized design, in a factorial scheme of eight salt concentrations $\left(0 ; 4.0 ; 8.0 ; 12.0 ; 16.0 ; 20.0 ; 24.0\right.$ and $\left.28.0 \mathrm{dS} \mathrm{m}^{-1}\right)$ and four temperatures $\left(25,30,35\right.$ and $\left.20-30{ }^{\circ} \mathrm{C}\right)$ in four replicates of 25 seeds under an 8 -h photoperiod in Biochemical Oxygen Demand germinators. The variables analyzed were: germination, germination speed index, shoot and root lengths, and shoot, root and total dry matter. Temperature variation influences the response of 'jurema-de-embira' seeds to salinity, and the salt stress is intensified by the increase in temperature. 'Jurema-de-embira' is tolerant to salt stress in the germination stage, showing satisfactory germination up to the salinity level $20 \mathrm{dS} \mathrm{m}^{-1}$, at temperatures below $30^{\circ} \mathrm{C}$. The initial growth of 'jurema-de-embira' plants is satisfactory up to salinity of $12 \mathrm{dS} \mathrm{m}^{-1}$, at temperatures below $30^{\circ} \mathrm{C}$.
\end{abstract}

\section{Palavras-chave:}

Fabaceae

espécie florestal

caatinga

salinidade

\section{Estresse salino e temperaturas na germinação e crescimento inicial de jurema-de-embira (Mimosa ophthalmocentra)}

\begin{abstract}
R E S U M O
Objetivou-se com esse trabalho avaliar os efeitos da salinidade sobre a germinação e crescimento inicial de plântulas de jurema-de-embira (Mimosa ophthalmocentra) em diferentes temperaturas. $\mathrm{O}$ experimento foi instalado em delineamento inteiramente casualizado, em esquema fatorial de oito concentrações salinas $(0 ; 4,0 ; 8,0 ; 12,0 ; 16,0 ; 20,0$; 24,0 e $\left.28,0 \mathrm{dS} \mathrm{m}^{-1}\right)$ e quatro temperaturas $\left(25,30,35\right.$ e $\left.20-30^{\circ} \mathrm{C}\right)$, em quatro repetições de 25 sementes, sob fotoperíodo de $8 \mathrm{~h}$ em germinadores do tipo Biochemical Oxygen Demand. As variáveis analisadas foram germinação, índice de velocidade de germinação, comprimento da parte aérea e da raiz, massa seca da parte aérea, raiz e total. A variação da temperatura influencia a resposta das sementes de jurema-de-embira à salinidade, sendo o estresse salino potencializado pelo aumento das temperaturas. A jurema-de-embira é tolerante na fase de germinação ao estresse salino, apresentando germinação satisfatória até o nível de salinidade $20 \mathrm{dS} \mathrm{m}^{-1}$, em temperaturas inferiores a $30^{\circ} \mathrm{C}$. O crescimento inicial das plantas de jurema-de-embira é satisfatório até a salinidade de $12 \mathrm{dS} \mathrm{m}^{-1}$, em temperaturas inferiores a $30^{\circ} \mathrm{C}$.
\end{abstract}




\section{INTRODUCTION}

'Jurema-de-embira' (Mimosa ophthalmocentra Mart. ex Benth.) is a species with high potential for wood production (Figueirôa et al., 2005), native to the Caatinga biome (Cavalcanti et al., 2009), which is also found in riparian forest areas (Lacerda et al., 2007) and in regeneration areas (Sampaio et al., 2010). As occurs for the other species of the Caatinga, there is little agronomic information on M. ophthalmocentra, especially regarding its propagation (Lima et al., 2006). Among the factors responsible for limiting its propagation in semiarid regions, soil salinity and high temperatures stand out, responsible for reducing germination and plant development (Sá et al., 2013; Souza, 2013).

Among the methods to determine plant tolerance to salt stress, the evaluation of germination and initial growth in saline substrate is one of the most widespread (Lima \& Torres, 2009). Good germination indices under salt stress conditions is an indication of tolerance to the stress (Sá et al., 2016). Temperature variations affect germination speed, percentage and uniformity (Marcos Filho, 2015), and optimal temperature is the one at which the combination of these variables is most efficient.

Some studies have been carried out to investigate the tolerance to salt stress as a function of temperature variations, such as Galindo (2010), with Crataeva tapia; Guedes et al. (2011), with Chorisia glaziovii and Souza (2013), with Swetenia macrophylla and Enterolobium contortisiliquum. Effects of salinity have also been observed by Lima \& Torres (2009), on Zizyphus joazeiro; Barreto et al. (2010), on Mimosa caesalpiniifolia; Freitas et al. (2010), on Caesalpinia ferrea; Nogueira et al. (2012), on Delonix regia; Guimarães et al. (2013), on Erythrina vellutina and Lima et al. (2015), on Albizia lebbeck, in which increasing salinity negatively affected germination and initial development of seedlings.

In this context, the objective was to evaluate the effects of salinity on germination and initial development of $M$. ophthalmocentra seedlings at different temperatures.

\section{Material ANd Methods}

'Jurema-de-embira' seeds were obtained from ripe fruits (pods) of 25 plants located in the municipality of Mossoró, RN ( $5^{\circ} 11^{\prime} 15^{\prime} \mathrm{S} ; 37^{\circ} 20^{\prime} 39^{\prime \prime} \mathrm{W} ; 16 \mathrm{~m}$ ). After collection, the seeds were manually removed, cleaned and dried in the shade. Then, they were fumigated, placed in cans and maintained in cold and dry chamber $\left(15{ }^{\circ} \mathrm{C}\right.$ and $50 \%$ of ambient $\left.\mathrm{RH}\right)$ until the evaluations.

The statistical design was completely randomized, in $4 \times 8$ factorial scheme (temperatures $\mathrm{x}$ salinity levels), and each treatment was composed of four replicates of 25 seeds.

Because these seeds have integumentary dormancy, their tips were cut using scissors on the end opposite to the hilum and planted on Germitest paper towel sheets moistened with saline solutions, in volume equivalent to 2.5 times the dry paper weight, produced with the addition of sodium chloride in distilled water until obtaining the preestablished salinity levels of $0,4,8,12,16,20,24$ and $28 \mathrm{dS} \mathrm{m} \mathrm{m}^{-1}$, measured using a digital conductivity meter.
Germination tests were carried out in Biochemical Oxygen Demand (BOD) germinators, regulated at constant temperatures of 25,30 and $35^{\circ} \mathrm{C}$, and alternated temperature of $20-30{ }^{\circ} \mathrm{C}(8 / 16 \mathrm{~h})$, with 8 -h photoperiod. Seeds were daily evaluated until 7 days after sowing and were considered as germinated when they produced the primary root and healthy seedling shoots (Brasil, 2009).

The variables analyzed were: a) germination percentage expressed in percentage of normal seedlings; b) germination speed index - measured simultaneously to the germination test, in which seedlings were daily evaluated from the beginning of germination to 7 days after sowing, and the index was calculated according to the equation proposed by Maguire (1962); c) shoot and root lengths - after the germination test, all normal seedlings of the experimental unit were measured for root length (plant base to root tip) and shoot (plant base to insertion of cotyledons) using a ruler graduated in centimeters; d) dry matter of shoots, roots and total - all normal seedlings of the experimental unit were separated into roots and shoots, dried in a forced-air oven at $65^{\circ} \mathrm{C}$ until constant weight $(48 \mathrm{~h})$ and weighed on precision analytical scale $(0.001 \mathrm{~g})$. Total dry matter was obtained by the sum of root dry matter and shoot dry matter.

The results were subjected to analysis of variance by $\mathrm{F}$ test at 0.05 probability level, using the statistical program SISVAR $^{\circledast}$ (Ferreira, 2014). In case of significance, the data were subjected to regression analysis using the software SigmaPlot. The model was selected based on the biological explanation and significance of the regression mean square.

\section{Results AND Discussion}

The interaction between salt concentrations and temperatures had significant influence $(\mathrm{p}<0.05)$ on all variables studied, except root dry matter, which was significantly influenced by the isolated factors (Table 1 and Figures 1, 2, 3 ). Increment in salinity reduced the germination of 'juremade-embira' seeds, and the salinity level causing reduction in germination decreased as temperature increased, being equal to $20.0,16.0,12.0$ and $8.0 \mathrm{dS} \mathrm{m}^{-1}$ for the temperatures of 20 $30,25,30$ and $35^{\circ} \mathrm{C}$, respectively. Salt stress intensely affected the germination of 'jurema-de-embira' seeds at temperature of $35{ }^{\circ} \mathrm{C}$ (Figure 1A), leading to null germination at the highest salinity level $\left(28 \mathrm{dS} \mathrm{m}^{-1}\right)$. This result occurs because high temperatures accelerate respiration and, consequently, increase water requirement, which is reduced due to the low osmotic potential of the substrate, thus resulting in seed deterioration (Guedes et al., 2011), inducing the reduction in germination and/or increase in the formation of abnormal seedlings and dead seeds.

The temperatures of $20-30$ and $25{ }^{\circ} \mathrm{C}$ caused less drastic effects, and the reduction in germination percentage (formation of normal seedlings) occurred from 20 and $16 \mathrm{dS} \mathrm{m}^{-1}$, but the most harmful effects occurred from the salinity level of $24 \mathrm{dS} \mathrm{m}^{-1}$, with reductions of 40.25 and $57.45 \%$, respectively (Figure 1A). Hence, seeds subjected to the lowest temperatures (2030 and $25^{\circ} \mathrm{C}$ ) showed lower respiration rate and lower water requirement, reducing the effects of the osmotic potential. 

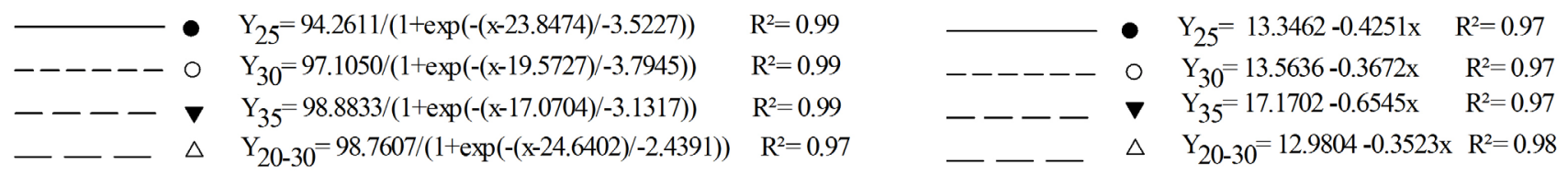

A.

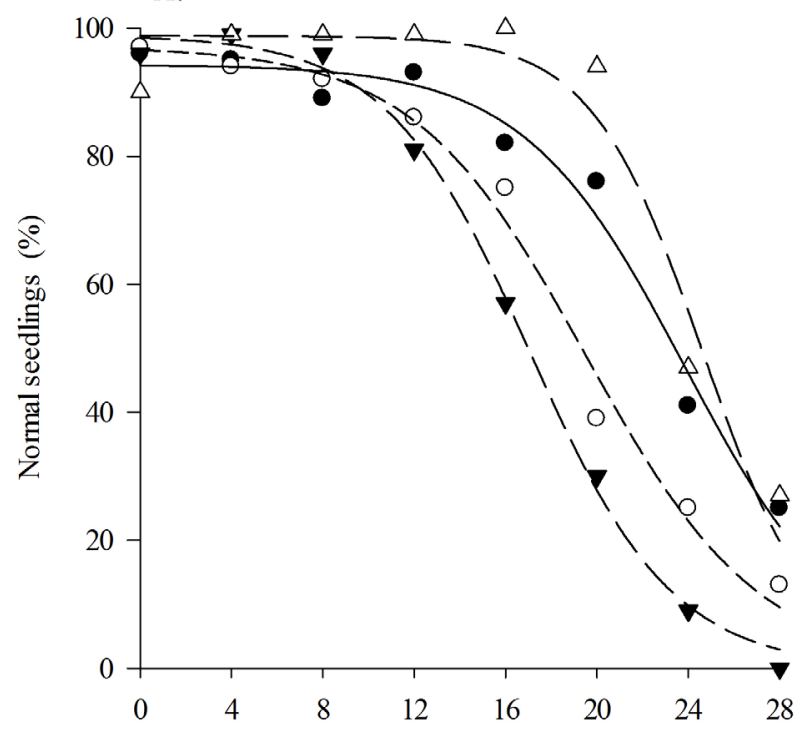

B.

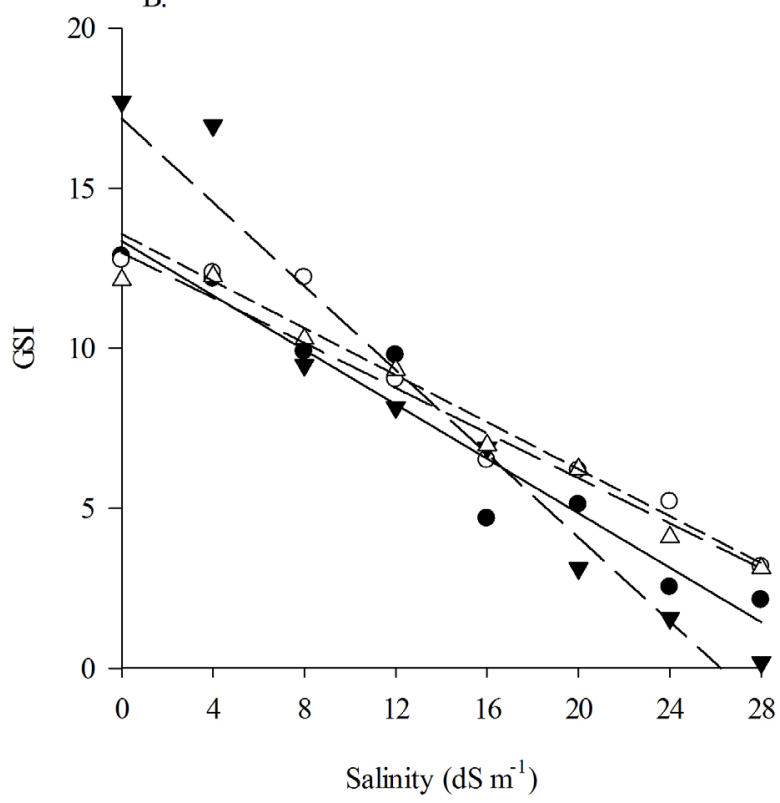

Salinity $\left(\mathrm{dS} \mathrm{m}^{-1}\right)$

Salinity $\left(\mathrm{dS} \mathrm{m}{ }^{-1}\right)$

Figure1. Percentage of normal seedlings (A) and germination speed index - GSI (B) of 'jurema-de-embira' seeds, subjected to salt stress at different temperatures

Under saline conditions, temperature variation has different effects on germination according to the species. Some seeds maintain their germination capacity after exposure to salinity (Khan \& Ungar, 1997). Thus, the interaction between temperature and salinity during germination plays an important role in determining the response to this process and a successful establishment in saline habitats (Ungar, 1995).

Greater reduction in the germination percentage of seeds subjected to salt stress at temperature of $35^{\circ} \mathrm{C}$ has also been observed by Galindo (2010), in C. tapia; Guedes et al. (2011), in C. glaziovii and Souza (2013), in S. macrophylla and E. contortisiliquum. According to Guedes et al. (2011), higher temperature $\left(35^{\circ} \mathrm{C}\right)$ can cause disintegration of protein structures and, along with the toxic effect and physiological drought caused by the levels of salts, led to reduction in seed germination.

The increase in salinity reduced germination speed, but in different ways for the temperatures studied (Figure 1B). Highest and lowest germination speeds were found in seeds maintained at temperature of $35^{\circ} \mathrm{C}$, at salinity levels of 0 and $28 \mathrm{dS} \mathrm{m}^{-1}$, respectively. It demonstrates that, although high temperatures accelerate metabolic processes in stressful situations (water deficit induced by the excess of salts), they tend to intensify the effects of salt stress on seed germination (Figure 1B).

At high temperatures, the speed of metabolic processes increases, shortening the duration of phase II in the soaking process. According to Nascimento (2005), very low or very high temperatures can alter both speed and final percentage of germination. Usually, low temperatures reduce germination speed, while high temperatures increase it. Reductions in GSI with the increment in salinity have also been observed by
Galindo (2010), in C. tapia; Guedes et al. (2011), in C. glaziovii and Souza (2013) in S. macrophylla and E. contortisiliquum.

Increased water salinity severely affected shoot length and root length in 'jurema-de-embira' seedlings. The reduction in the shoots was more noticeable at temperatures of 35 and $20-30^{\circ} \mathrm{C}$ from the salinity level of $8.0 \mathrm{dS} \mathrm{m}^{-1}$ and, for root length, at temperatures of 25 and $30^{\circ} \mathrm{C}$ from $4.0 \mathrm{dS} \mathrm{m}^{-1}$ (Figures $2 \mathrm{~A}$ and $\mathrm{B})$. It can be pointed out that, at temperatures of 25 and $30{ }^{\circ} \mathrm{C}$, plants invest more in shoot growth and, consequently, this part develops more than the root system. This is an important mechanism of plant tolerance to salinity, which aims to reduce root surface and, therefore, decrease the entry of water and ions in the plant, increasing the selectivity and reducing the risk of toxicity by specific ions (Esteves \& Suzuki, 2008; Muns \& Tester, 2008; Sá et al., 2016). On the other hand, seeds germinated at temperature of $35{ }^{\circ} \mathrm{C}$ obtained greater root development compared with the shoots, which denotes that plants under water deficit conditions induced by saline and thermal stress use their energy in the development of the root system in the search for water. In general, shoots tend to grow until water absorption by roots becomes limiting to growth; conversely, roots tend to grow until the demand for photosynthates, from the shoots, exceeds the supply (Taiz \& Zeiger, 2013).

Likewise, Guedes et al. (2011) and Galindo (2010) found that the length of C. glaziovii and C. tapia L. seedlings, respectively, was affected as salinity levels increased, regardless of temperature. In contrast, Souza (2013) observed that the growth of S. macrophylla and E. contortisiliquum seedlings was not sensitive to salinity.

For root dry matter, a decreasing linear response was found, with linear reductions of $0.0273 \mathrm{~g}$ for each unit increment in water salinity, regardless of the temperature at which seeds 

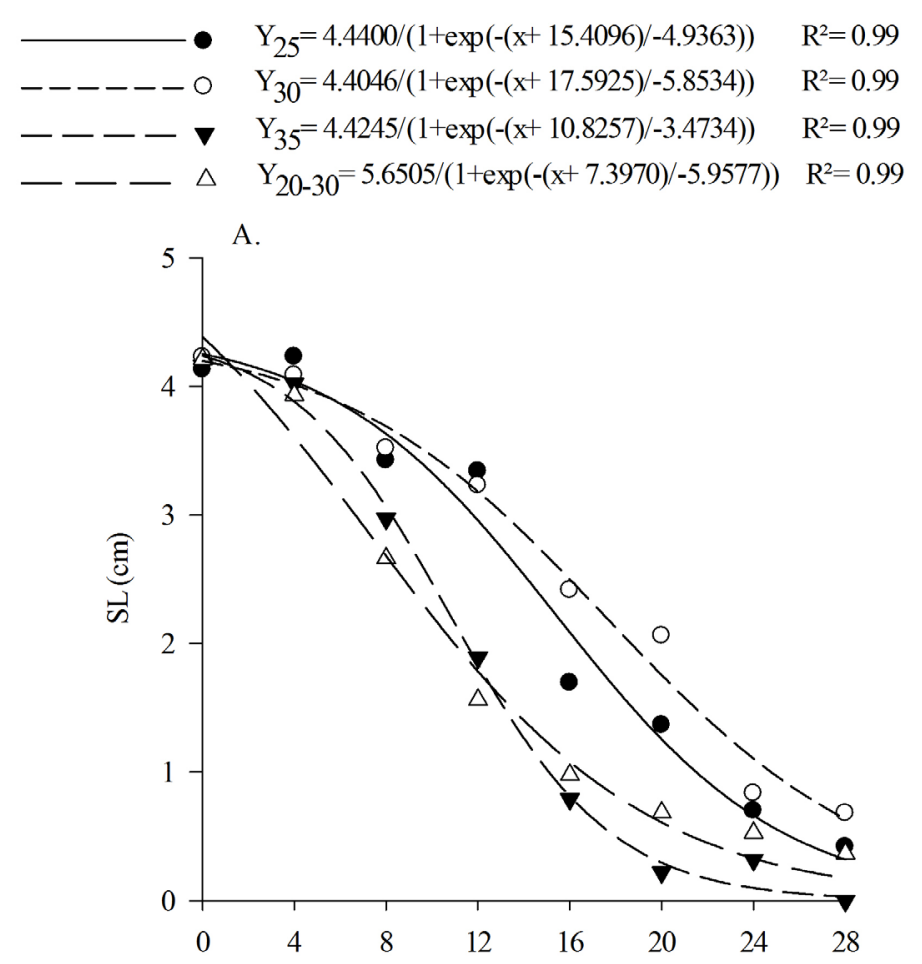

Salinity $\left(\mathrm{dS} \mathrm{m}^{-1}\right)$

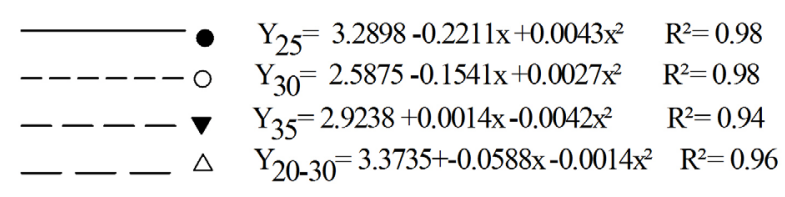

B.

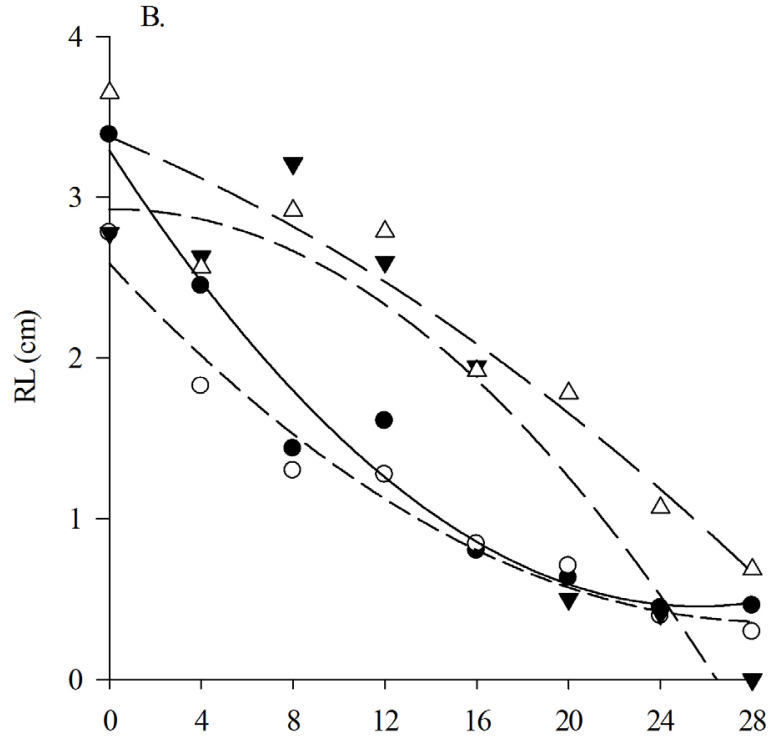

Salinity $\left(\mathrm{dS} \mathrm{m}^{-1}\right)$

Figure 2. Shoot length - SL (A) and root length - RL (B) of 'jurema-de-embira' seedlings subjected to salt stress at different temperatures

were germinated (Figure $3 \mathrm{~A}$ ). This reduction comprehends a total value of $67 \%$ comparing the results obtained at the lowest $\left(0 \mathrm{dS} \mathrm{m}^{-1}\right)$ and highest $\left(28.0 \mathrm{dS} \mathrm{m}^{-1}\right)$ levels of water electrical conductivity. For the temperatures, the dry matter accumulation in the roots of seedlings subjected to temperature of $35^{\circ} \mathrm{C}$ was lower than that of seedlings subjected to 25,30 and $20-30^{\circ} \mathrm{C}$ (Table 1 ), thus denoting that the temperature of $35{ }^{\circ} \mathrm{C}$ causes thermal stress on the germination of juremade-embira' seeds, and their optimal temperature is within the range from 20 to $30^{\circ} \mathrm{C}$.

Under hydration with saline water at temperature of $20-30^{\circ} \mathrm{C}$, no expressive reductions were found in shoot dry matter and total dry matter until the salinity level of $28 \mathrm{dS} \mathrm{m}^{-1}$ (Figures
Table 1. Means of root dry matter (RDM) of 'jurema-deembira' seedlings subjected to different temperatures

\begin{tabular}{cc}
\hline Temperature $\left({ }^{\circ} \mathrm{C}\right)$ & RDM $\left(\mathrm{g}\right.$ seedling $\left.{ }^{-1}\right)$ \\
25 & $0.55 \mathrm{a}^{*}$ \\
30 & $0.47 \mathrm{a}$ \\
35 & $0.36 \mathrm{~b}$ \\
$20-30$ & $0.55 \mathrm{a}$ \\
\hline
\end{tabular}

*Means followed by the same lowercase letter in the column do not differ by Tukey test at 0.05 probability level

$3 \mathrm{~B}$ and $\mathrm{C})$. At temperatures of 25 and $30{ }^{\circ} \mathrm{C}$, these variables linearly decreased by 30 and $36 \%$ between the lowest $\left(0 \mathrm{dS} \mathrm{m} \mathrm{m}^{-1}\right)$ and highest $\left(28.0 \mathrm{dS} \mathrm{m}^{-1}\right)$ salinity levels. At temperature of $35^{\circ} \mathrm{C}$, shoot dry matter and total dry matter decreased after

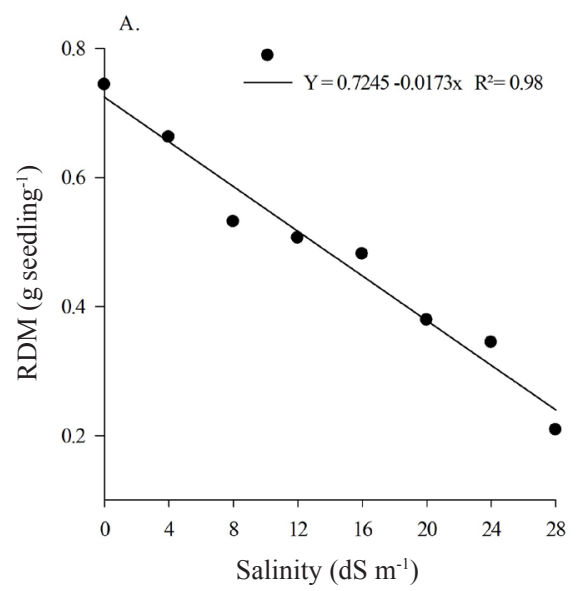

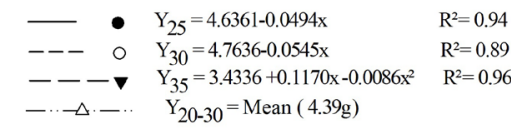

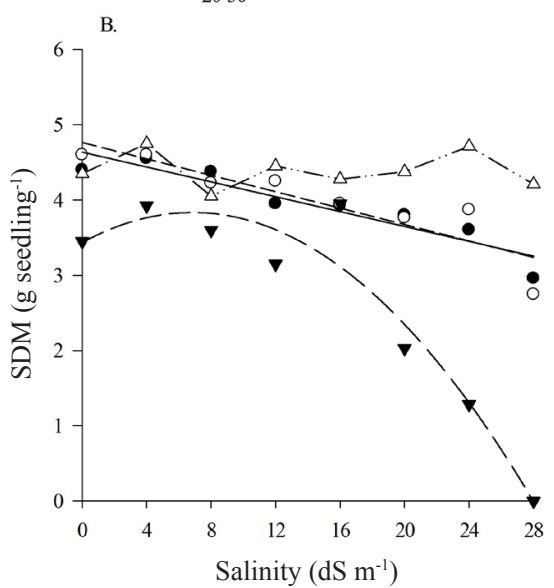

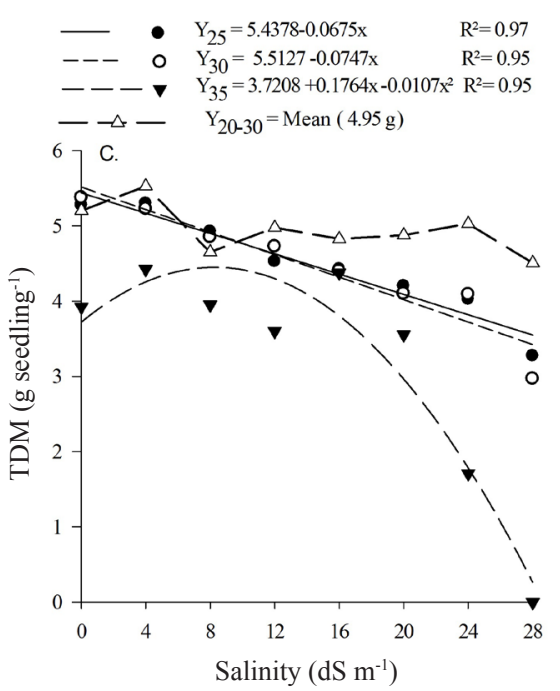

Figure 3. Root dry matter - RDM (A), shoot dry matter - SDM (B) and total dry matter - TDM (C) of 'jurema-de-embira' seedlings subjected to salt stress at different temperatures 
the estimated levels of 6.80 and $8.24 \mathrm{dS} \mathrm{m}^{-1}$, respectively. From these points on, drastic reductions occurred, with null dry matter accumulation at salinity of $28 \mathrm{dS} \mathrm{m} \mathrm{m}^{-1}$ (Figures $3 \mathrm{~B}$ and C). Shoot dry matter and total dry matter curves are similar because roots represent a very small fraction of the total dry matter (less than 20\%). Hence, the shoots determined the behavior of the curves.

A similar reduction in dry matter was observed by Galindo et al. (2010) in C. tapia seedlings, and total dry matter decreased as salinity increased. The greatest reduction was caused by the temperature of $35^{\circ} \mathrm{C}$, while at $25^{\circ} \mathrm{C}$ there was almost no reduction in the total dry matter of the seedlings. Non-significant reductions in seedling dry matter as salinity increased were also observed by Souza (2013), in S. macrophylla and E. contortisiliquum.

\section{Conclusions}

1. Temperature variation influences the response of 'juremade-embira' seeds to salinity, and the salt stress is intensified by its increase.

2. 'Jurema-de-embira' is tolerant to salt stress in the germination stage, showing satisfactory germination until the salinity level of $16 \mathrm{dS} \mathrm{m} \mathrm{m}^{-1}$, at temperatures below $30^{\circ} \mathrm{C}$.

3. The initial growth of 'jurema-de-embira' seedlings is

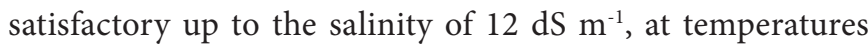
below $30^{\circ} \mathrm{C}$.

\section{Literature Cited}

Barreto, H. B. F.; Freitas, R. M. O.; Oliveira, L. A. A.; Araújo, J. A. M.; Costa, E. M. Efeito da irrigação com água salina na germinação de sementes de sábia (Mimosa caesalpiniifolia Benth). Revista Verde de Agroecologia e Desenvolvimento Sustentável, v.5, p.125-130, 2010.

Brasil. Ministério da Agricultura, Pecuária e Abastecimento. Regras para análise de sementes. Ministério da Agricultura, Pecuária e Abastecimento. Secretaria de Defesa Agropecuária. Brasília: MAPA/ACS, 2009. 399p.

Cavalcanti, A. D. C.; Rodal, M. J. N.; Sampaio, E. V. S. B.; Costa, K. C. C. Mudanças florísticas e estruturais, após cinco anos, em uma comunidade de caatinga no estado de Pernambuco, Brasil. Acta Botânica Brasílica, v.23, p.1210-1212, 2009. https://doi. org/10.1590/S0102-33062009000400032

Esteves, B. S.; Suzuki, M. S. Efeito da salinidade sobre as plantas. Oecologia Brasiliensis, v.12, p.662-679, 2008. https://doi. org/10.4257/oeco.2008.1204.06

Ferreira, D. F. Sisvar: A guide for its bootstrap procedures in multiple comparisons. Ciência e Agrotecnologia, v.38, p.109-112, 2014 https://doi.org/10.1590/S1413-70542014000200001

Figueirôa, J. M.; Pareyn, F. G. C.; Drumond, M.; Araújo, E. L. Madeireiras. In: Sampaio, E. V. S. B (ed.). Espécies da flora nordestina de importância econômica potencial. Recife: Associação Plantas do Nordeste (APNE), 2005. Cap.6, p.101-133.

Freitas, R. M. O.; Nogueira, N. W.; Oliveira, F. N.; Costa, E. M.; Ribeiro, M. C. C. Efeito da irrigação com água salina na emergência e crescimento inicial de plântulas de Jucá. Revista Caatinga, v.23, p.54-58, 2010.
Galindo, E. A. Tecnologia de sementes de Crataeva tapia L. Areia: Centro de Ciências Agrárias/Universidade Federal da Paraíba, 2010. 92p. Dissertação Mestrado

Guedes, R. S.; Alves, E. U.; Galindo, E. A.; Barrozo, L. M. Estresse salino e temperaturas na germinação e vigor de sementes de Chorisia glaziovii O. Kuntze. Revista Brasileira de Sementes, v.33, p.279288, 2011. https://doi.org/10.1590/S0101-31222011000200010

Guimarães, I. P.; Oliveira, F. N.; Vieira, F. E. R.; Torres, S. B. Efeito da salinidade da água de irrigação na emergência e crescimento inicial de plântulas de mulungu. Revista Brasileira de Ciências Agrárias, v.8, p.137-142, 2013. https://doi.org/10.5039/agraria. v8i1a2360

Khan, M. A.; Ungar, I. A. Effect of light, salinity, and thermoperiod on the seed germination of halophytes. Canadian Journal of Botany, v.75, p.835-841, 1997. https://doi.org/10.1139/b97-093

Lacerda, A. V.; Barbosa, F. M.; Barbosa, M. R. V. Estudo do componente arbustivo-arbóreo de matas ciliares da bacia do rio Taperoá, semiárido paraibano: Uma perspectiva para a sustentabilidade dos recursos naturais. Oecologia Brasiliensis, v.11, p.331-340, 2007. https://doi.org/10.4257/oeco.2007.1103.03

Lima, B. G.; Torres, S. B. Estresses hídrico e salino na germinação de sementes de Zizyphus joazeiro Mart. (Rhamnaceae). Revista Caatinga, v.22, p.93-99, 2009.

Lima, J. D.; Almeida, C. C.; Dantas, V. A. V.; Silva, B. M. S.; Moraes, W. Efeito da temperatura e dos substratos na germinação de sementes de Caesalpinia ferrea Mart. ex. Tul. (Leguminosae). Revista Árvore, v.30, p.513-518, 2006. https://doi.org/10.1590/ S0100-67622006000400003

Lima, M. F. P.; Porto, M. A. F.; Torres, S. B.; Freitas, R. M. O.; Nogueira, N. W.; Carvalho, D. R. Emergência e crescimento inicial de plântulas de albízia submetidas à irrigação com água salina. Revista Brasileira de Engenharia Agrícola e Ambiental, v.19, p.3-8, 2015. https://doi.org/10.1590/1807-1929/agriambi. v19n2p106-112

Maguire, J. D. Speed of germination-aid in selection and evaluation for seedling emergence and vigor. Crop Science, v.2, p.176-177, 1962. https://doi.org/10.2135/cropsci1962.0011183X000200020033x

Marcos Filho, J. Fisiologia de sementes de plantas cultivadas. Londrina: ABRATES, 2015. 659p.

Munns, R.; Tester, M. Mechanism of salinity tolerance. Annual Review of Plant Biology, v.59, p.651-681, 2008. https://doi.org/10.1146/ annurev.arplant.59.032607.092911

Nascimento, W. M. Condicionamento osmótico de sementes de hortaliças visando a germinação em condições de temperaturas baixas. Horticultura Brasileira, v.23, p.211-214, 2005. https://doi. org/10.1590/S0102-05362005000200010

Nogueira, N. W.; Lima, J. S. S.; Freitas, R. M. O.; Ribeiro, M. C. C.; Leal, C. C. P.; Pinto, J. R. S. Efeito da salinidade na emergência e crescimento inicial de plântulas de flamboyant. Revista Brasileira de Sementes, v.34, p.466-472, 2012. https://doi.org/10.1590/ S0101-31222012000300014

Sá, F. V. S.; Araújo, J. L.; Novais, M. C.; Silva, A. P.; Pereira, F. H. F.; Lopes, K. P. Crescimento inicial de arbóreas nativas em solo salinosódico do Nordeste brasileiro tratado com acondicionadores. Revista Ceres, v.60, p.388-396, 2013. https://doi.org/10.1590/ S0034-737X2013000300012 
Sá, F. V. S.; Paiva, E. P.; Torres, S. B.; Brito, M. E. B.; Nogueira, N. W.; Frade, L. J. G.; Freitas, R. M. O. Seed germination and vigor of different cowpea cultivars under salt stress. Comunicata Scientiae, v.7, p.450-455, 2016. https://doi.org/10.14295/cs.v7i4.1541

Sampaio, E.; Gasson, P.; Baracat, A.; Cutler, D.; Pareyn, F.; Lima, K. C. Tree biomass estimation in regenerating areas of tropical dry vegetation in northeast Brazil. Forest Ecology and Management, v.259, p.11351140. 2010. https://doi.org/10.1016/j.foreco.2009.12.028
Souza, R. S. Potencial de espécies florestais nativas na fitoextração de sais. Cuiabá: Universidade Federal do Mato Grosso, 2013. 63p. Dissertação Mestrado

Taiz, L.; Zeiger, E. Fisiologia vegetal. 5.ed. Porto Alegre: Artmed, 2013. 954p.

Ungar, I. A. Seed germination and seed-bank ecology of halophytes. In: Kiegel, J.; Galili, G. (org.). Seed development and germination. New York: Marcel and Dekker Inc., 1995. Chap.23, p.599-628. 